Glucose

Hexokinase II

Glucose -6-P

Phosphoglucomutase

Glucose -1-P

UDP-Glucopyrophosphorylase

UDP-Glucose

Glycogenin

Glycogen (chain initiation, Glucose ${ }_{2}$ )

\section{Glycogen synthase}

Glycogen (Glucose) $)_{n+1}$
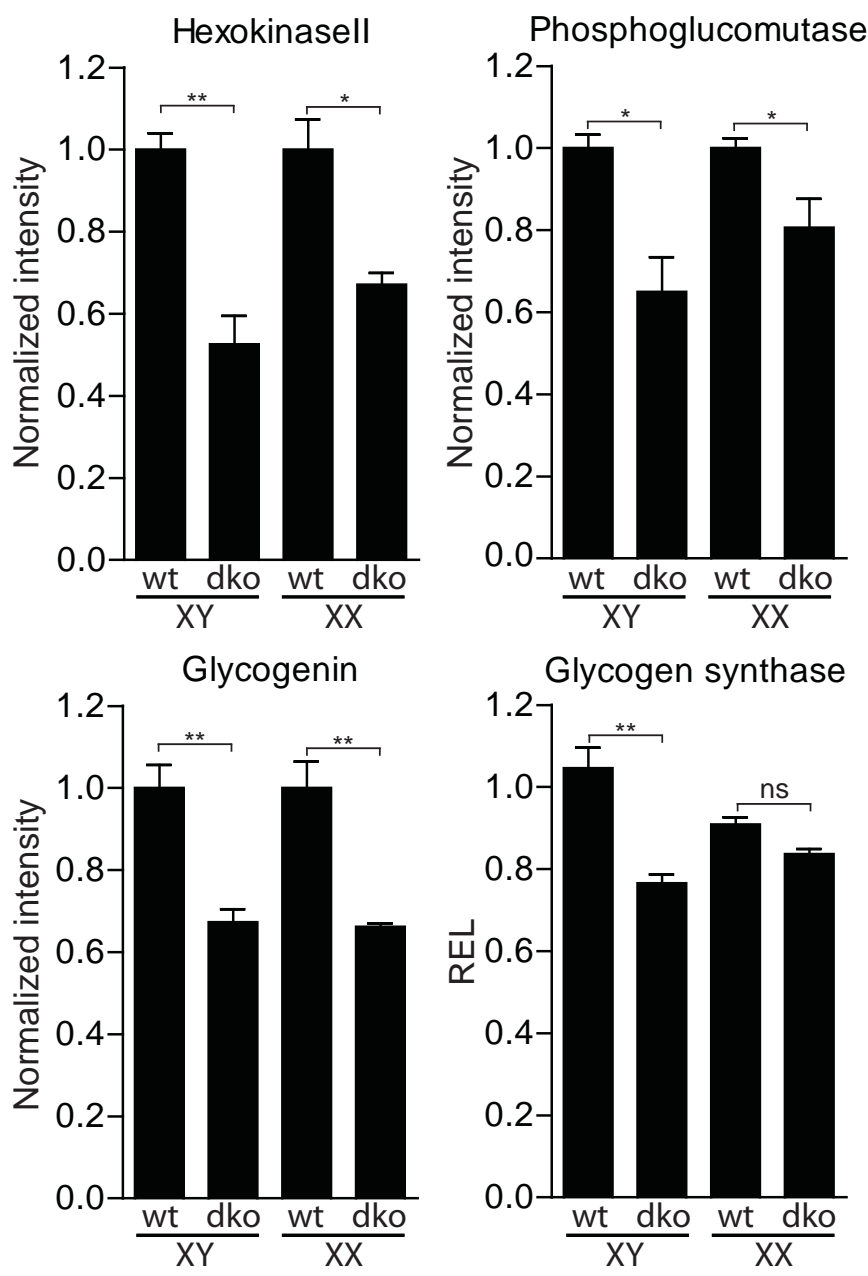